\title{
Effect of bulking materials over the composting of bio-slurry
}

\author{
M Al-Amin ${ }^{1}$, MM Rahman ${ }^{1}$, SMA Islam ${ }^{1}$, H Dhakal ${ }^{1,2}$, MRI Khan $^{1}$, MR Amin $^{1}$ and AKMA Kabir ${ }^{1 *}$
}

${ }^{1}$ Department of Animal Science, Bangladesh Agricultural University, Mymensingh-2202, Bangladesh; ${ }^{2}$ Scientist, Nepal Agriculture Research Council, Nepal.

\begin{abstract}
Bio-slurry is considered as a good quality organic fertilizer in Bangladesh agriculture. An experiment was conducted at Bangladesh Agricultural University, Mymensingh to assess the effect of bulking materials over the composting of bio-slurry. The experiment was conducted with 4 treatments each of 3 replications. The treatments for compost preparation were, $\mathrm{T}_{0}\left(50 \%\right.$ Bio-slurry $+50 \%$ manure), $\mathrm{T}_{1}(50 \%$ Bio-slurry $+50 \%$ manure and saw dust), $\mathrm{T}_{2}\left(50 \%\right.$ Bio-slurry $+50 \%$ manure and rice straw), $\mathrm{T}_{3}(50 \%$ Bio-slurry $+50 \%$ manure and tree leaves). Compost moisture, $\mathrm{pH}$, temperature and $\mathrm{C}$ : $\mathrm{N}$ ratio was assessed every week. Maximum temperature found in $\mathrm{T}_{1}\left(34.03^{\circ} \mathrm{C}\right)$ and other treatments showed a slower rise in temperature. Highest $\mathrm{C}: \mathrm{N}$ ratio $(19.30)$ was obtained in $\mathrm{T}_{3}$. The $\mathrm{pH}$ of the compost was significantly influenced by saw dust which ranged from 8.28 in $T_{2}$ to 8.74 in $T_{1}$. Moisture content of compost was significantly influenced by bulky materials and ranged from 56.34 to 68.83 . At 42 day the highest crude fiber was obtained in $\mathrm{T}_{2}(25.16 \%)$. The results suggest that bulky materials treated bioslurry can be good compost which will be very effective to soil and crops.
\end{abstract}

Key words: bio-slurry, composting, agricultural waste, bulking material

Bangladesh Animal Husbandry Association. All rights reserved. $\quad$ Bang. J. Anim. Sci. 2020. 49 (2):142-150

\section{Introduction}

Bio-slurry is anaerobic digested manure released as by-product from bio-gas plant after production of combustible methane gas for cooking lighting, and/or running machineries (Islam, 2013). It may be considered as an effective source of organic fertilizer as it contains considerable amounts of primary nutrients, namely nitrogen, phosphorus and potassium (NPK) and organic matter that are readily absorbed by plants and soil micro-flora (Islam, 2006). The composition of Bio-slurry depends upon several factors: the kind of dung (animal or human), water, breed and age of animals, types of feed and feeding rate (Warnars and Oppenoorth, 2014). Among the organic materials, cow dung is used to produce the Bioslurry. The cow dung is fermented for 50 days after which the slurry is discarded (South Netherlands Volunteers Royal Society for Protection of Nature, 2012). It is said to be a good source of nutrients for most plants, especially for fruit bearing trees, vegetables and other horticultural crops (Mohabbat et al., 2008). Bio-slurry improves the physical, chemical, and biological qualities of soil, including soil structure, water holding capacity, CEC, lowering soil bulk density, protection against soil erosion, preventing the leaching of nutrients and it also provides nutrients to soil micro-flora and fauna (Fentaw, 2010). Therefore, Bio-slurry is a good organic fertilizer that can be used together with inorganic nitrogenous fertilizers to improve soil fertility (Satyanarayana et al., 2002; Garg et al., 2005).

The beneficial effect of bio-slurry in crops production has been demonstrated by many workers (Mohabbat et al., 2008). Maintenance of soil fertility is a prerequisite for long term sustainable crop production and organic fertilizers. A very good example is that cow dung and poultry manure or their slurry can play a vital role in the sustainability of soil fertility and crop production (Mohabbat et al., 2008). Now utilization and management of Bio-slurry is a challenge for Bangladesh. Bio-slurry can be used in liquid, dried or composted form (Dhobighat and Painyapani, 2006). Bio-slurry can be used to fertilize crops directly or added to composting of other organic materials. Bio-slurry is an alreadydigested source of animal waste and if urine (animal and/or human) is added, more nitrogen is added to the bio-slurry which can speed up the compost making process (Warnars and Oppenoorth, 2014). This improves the carbon/nitrogen $(\mathrm{C} / \mathrm{N})$ ratio in the compost. But this also depends on the kind of digester. With the right amounts of materials, the composition 
of the bio-slurry can be $93 \%$ water and $7 \%$ dry matter, of which $4.5 \%$ is organic matter and $2.5 \%$ inorganic matter (Warnars and Oppenoorth, 2014). Hence, digested bio-slurry can be a precious alternative to synthetic fertilizers. Biogas slurry is considered a good source of organic fertilizer as it contains considerable amounts of both macro $(\mathrm{N}, \mathrm{P}, \mathrm{K})$ and micronutrients $(\mathrm{Zn}, \mathrm{Mn}, \mathrm{B})$ that are necessary for plant growth (Alam, 2006). Use of biogas slurry is providing a sustainable way for agriculture, environment and farming communities. The study was conducted under the aim of utilization of Bio-slurry waste into valuable fertilizer by composting with different agricultural wastes as moisture absorbent.

\section{Materials and Method}

\section{Experimental site and duration}

The experiment was conducted at Sheep and Goat Farm of the Department of Animal Science, Bangladesh Agricultural University, Mymensingh. The composting period was 45 days i.e 12 February to 24 April 2019. The chemical analysis of Bio-slurry and composted Bio-slurry was performed in the Departmental laboratory.

\section{Treatments of the experiment}

To fulfill the objectives, four experiments were conducted e.g. anaerobic composting $\mathrm{T}_{0}(50 \%$ Bio-slurry $+50 \%$ manure $), \mathrm{T}_{1}(50 \%$ Bio-slurry + $50 \%$ manure and saw dust), $\mathrm{T}_{2}$ (50\% Bio-slurry $+50 \%$ manure and rice straw), $\mathrm{T}_{3}(50 \%$ Bioslurry $+50 \%$ manure and tree leaves) under soil surface to develop convenient method of composting Bio-slurry. The sample was collected at $0,7,14,21,28,35,42^{\text {th }}$ days for analysis. In each treatment there were three replications to minimize the experimental errors.

\section{Collection of raw materials}

The Bio-slurry, rice straw, tree leaves were collected from the Goat, Sheep and Horse Farm of Bangladesh Agricultural University. Saw dusts were collected from Babul saw mill, Seshmore, BAU, Mymensingh. The raw materials were carried into sac at the Animal Science Field Laboratory and stored in the air tight condition.

\section{Preparation of compost pit}

A place of comparatively high land at Animal Science Field Laboratory was selected to prepare holes where rain water was not logged. At first the place was cleaned and then 12 similar pits were prepared whose diameter was $75 \mathrm{~cm}$ and depth $45 \mathrm{~cm}$. Polyethylene bags were set at the bottom and side wall of pits to prevent leaching and water contamination with compost.

\section{Preparation of mixture for composting}

After collection the sample was mixed properly and divided each sample in 3 parts of $40 \mathrm{~kg}$ then bulking materials were mixing with the sample to fix the moisture level at $70 \%$. No treatment was given rest of the parts.

\section{Routine activities during composting} process:

The composting materials in the composting pits were turned and mixed at every 7 day intervals. The composting materials under decomposition were collected just after turning and mixing the materials and collected samples were analyzed for the following attributes:

\section{Moisture content:}

Moisture content was determined by gravimetric method.

\section{Temperature}

Temperature was determined by soil thermometer (Easy-Read Thermometer).

\section{pH}

The $\mathrm{pH}$ of the composting materials during composting process was determined by Glass Electrode $\mathrm{pH}$ meter.

\section{Total Nitrogen}

The total nitrogen was determined by MicroKjeldhal method as outline by Jackson (1962) through the digester of organic matter.

\section{$C / N$ ratio}

Total organic carbon was divided by total nitrogen.

\section{Analysis of data}

Data collected on different parameters under this study were statistically analyzed to ascertain in the significant differences between treatments. The distribution of data for normality was checked before data analysis. All data were normally distributed. The data were analyzed for in a Completely Randomized Design (CRD) (SAS Software). 


\section{Bio-slurry compost adding with bulking materials}

\section{Results}

\section{Analysis of Bio-slurry}

The moisture, $\mathrm{pH}, \mathrm{C} / \mathrm{N}$ ratio, total nitrogen content of Bio-slurry were analyzed and are summarized in the Table 1 . The level of moisture was $(85.04 \%)$ and $\mathrm{pH}$ (8.63). The nitrogen content $(1.18 \%)$ was not so bad and $\mathrm{C} / \mathrm{N}$ ratio was also moderate.

Table 1: Analysis of bio-slurry collected from Goat and Sheep farm, BAU, Mymensingh

\begin{tabular}{lc}
\hline Parameter & Composition of Bio-slurry \\
\hline Moisture & $85.04 \%$ \\
$\mathrm{pH}$ & 8.63 \\
Total N & $1.18 \%$ \\
$\mathrm{C} / \mathrm{N}$ ratio & 18.90 \\
\hline
\end{tabular}

\section{Crude Fiber (CF) analysis of compost}

The crude fiber content of compost was analyzed and summarized in the Table 2 . The crude fibre content at 42 day was in the range of 22.07 to
$25.16 \%$. The highest CF obtained in $\mathrm{T}_{2}$ (25.165) and the lowest $\mathrm{CF}$ obtained in $\mathrm{T}_{1}$.

Table 2: Analysis of crude fiber (CF) of different treatments

\begin{tabular}{lc}
\hline Treatments & Crude Fiber (\%) \\
\hline $\mathrm{T}_{1}$ & 22.07 \\
$\mathrm{~T}_{2}$ & 25.16 \\
$\mathrm{~T}_{3}$ & 24.39 \\
$\mathrm{~T}_{4}$ & 23.19 \\
\hline
\end{tabular}

$T_{0}, 50 \%$ bio-slurry $+50 \%$ manure; $T_{1}, 50 \%$ bioslurry + 50\% manure + saw dust; $T_{2}, 50 \%$ bioslurry $+50 \%$ manure + rice straw; $T_{3}, 50 \%$ bioslurry $+50 \%$ manure + tree leaves.

\section{Changing pattern of different parameters during composting}

\section{pH}

The $\mathrm{pH}$ plays a vital role in the decomposition process. The initial $\mathrm{pH}$ range of the treatment sample was alkaline (8.28-8.69). With the progress in composting the $\mathrm{pH}$ declined to 8.14 $\left(\mathrm{T}_{3}\right)$ at $2^{\text {nd }}$ week (Figure-1). After 3rd week all treatments showed an increasing $\mathrm{pH}$. All the treatments showed declining $\mathrm{pH}$ after $5^{\text {th }}$ week.

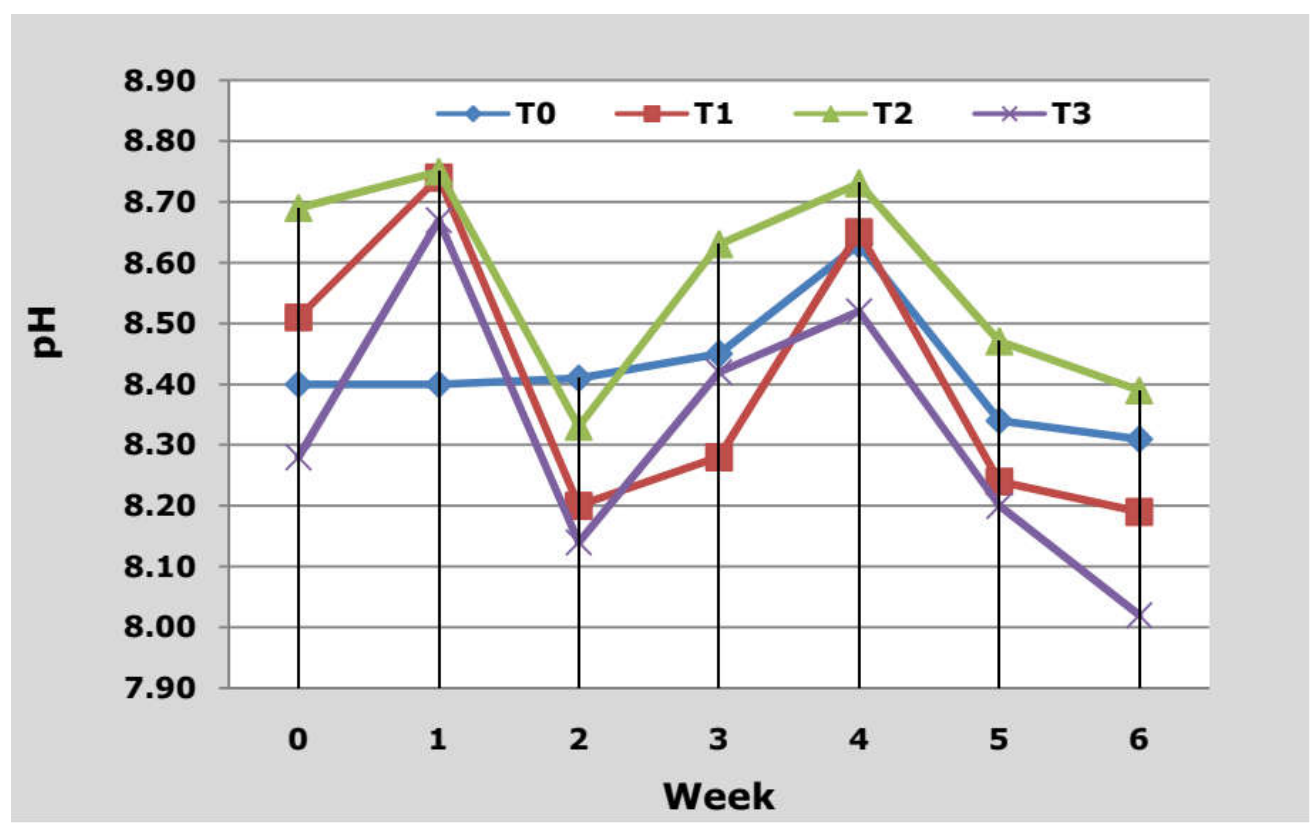

$T_{0}, 50 \%$ bio-slurry $+50 \%$ manure; $T_{1}, 50 \%$ bio-slurry $+50 \%$ manure + saw dust; $T_{2}, 50 \%$ bio-slurry $+50 \%$ manure + rice straw; $T_{3}, 50 \%$ bio-slurry $+50 \%$ manure + tree leaves.

Figure 1: Changing pattern of $\mathrm{pH}$ during composting of bio-slurry 
Al-Amin et al. (2020) Bang. J. Anim. Sci. 49 (2):142-150

\section{Moisture content (MC)}

Moisture is necessary to support the metabolic processes of the microbes. Moisture percentage as measured at the beginning of work around $72.22 \%$ in all the pits and highest moisture content was observed in $T_{0}$. At the end of $1^{\text {st }}$ week of after treatment with bulky materials the moisture percentage of the composting material reduced in treated pit. In $\mathrm{T}_{2}$ pit, moisture was a significantly lower. Moisture in the pits decreased over time. The trend continued to the end of $6^{\text {th }}$ week of composting. At the end of $6^{\text {th }}$ week, the moisture percentage varied from 56$68 \%$. The untreated Bio-slurry had the highest moisture percentage $(68.83 \%)$ while $T_{1}$ pits carried the lowest moisture (56.34\%) (Figure 2).

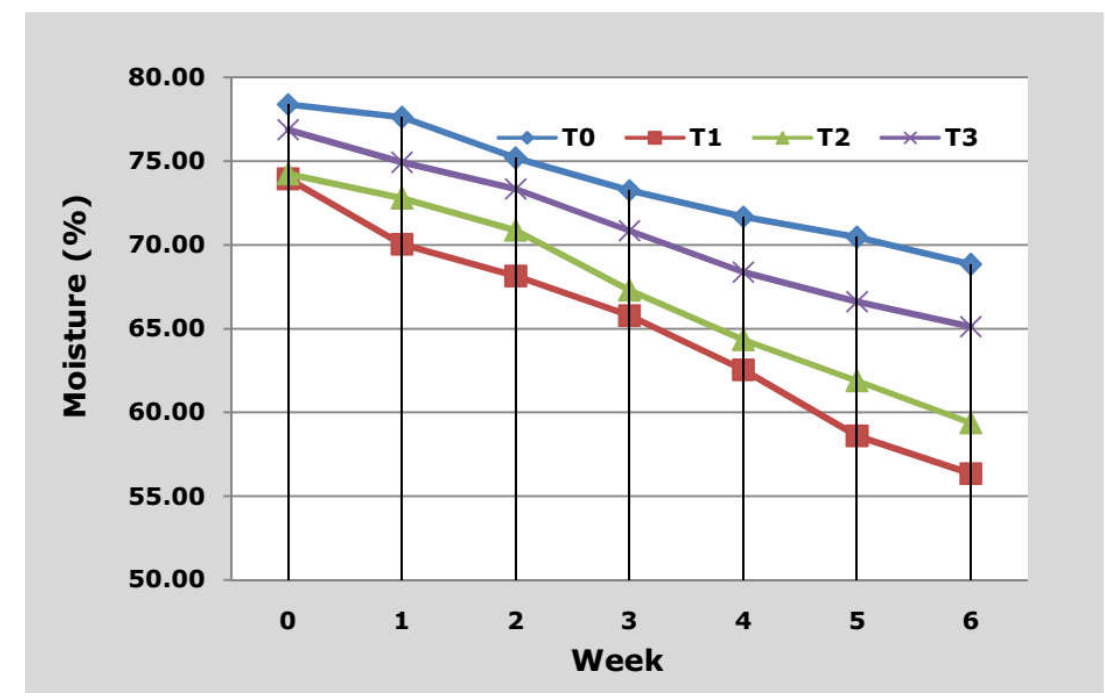

$T_{0}, 50 \%$ bio-slurry $+50 \%$ manure; $T_{1}, 50 \%$ bio-slurry $+50 \%$ manure + saw dust; $T_{2}, 50 \%$ bio-slurry $+50 \%$ manure + rice straw; $T_{3}, 50 \%$ bio-slurry $+50 \%$ manure + tree leaves.

Figure 2: Changing pattern of moisture (\%) during composting of bio-slurry

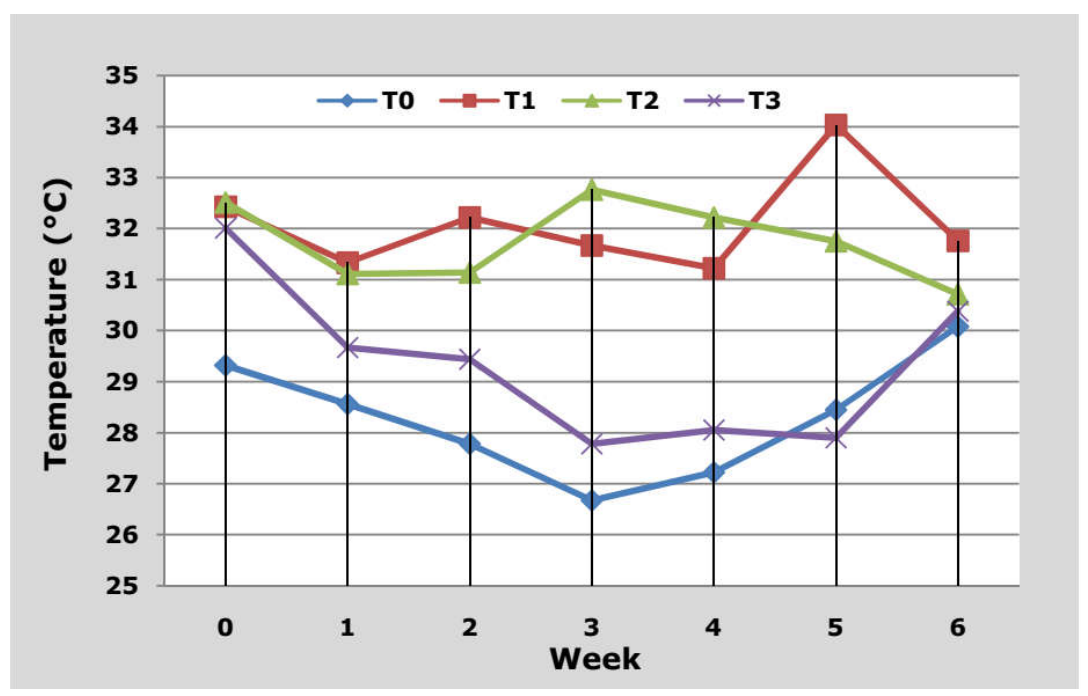

$T_{0}, 50 \%$ bio-slurry $+50 \%$ manure; $T_{1}, 50 \%$ bio-slurry $+50 \%$ manure + saw dust; $T_{2}, 50 \%$ bio-slurry $+50 \%$ manure + rice straw; $T_{3}, 50 \%$ bio-slurry $+50 \%$ manure + tree leaves.

Figure 3: Changing pattern of temperature $\left({ }^{\circ} \mathrm{C}\right)$ during composting of bio-slurry 


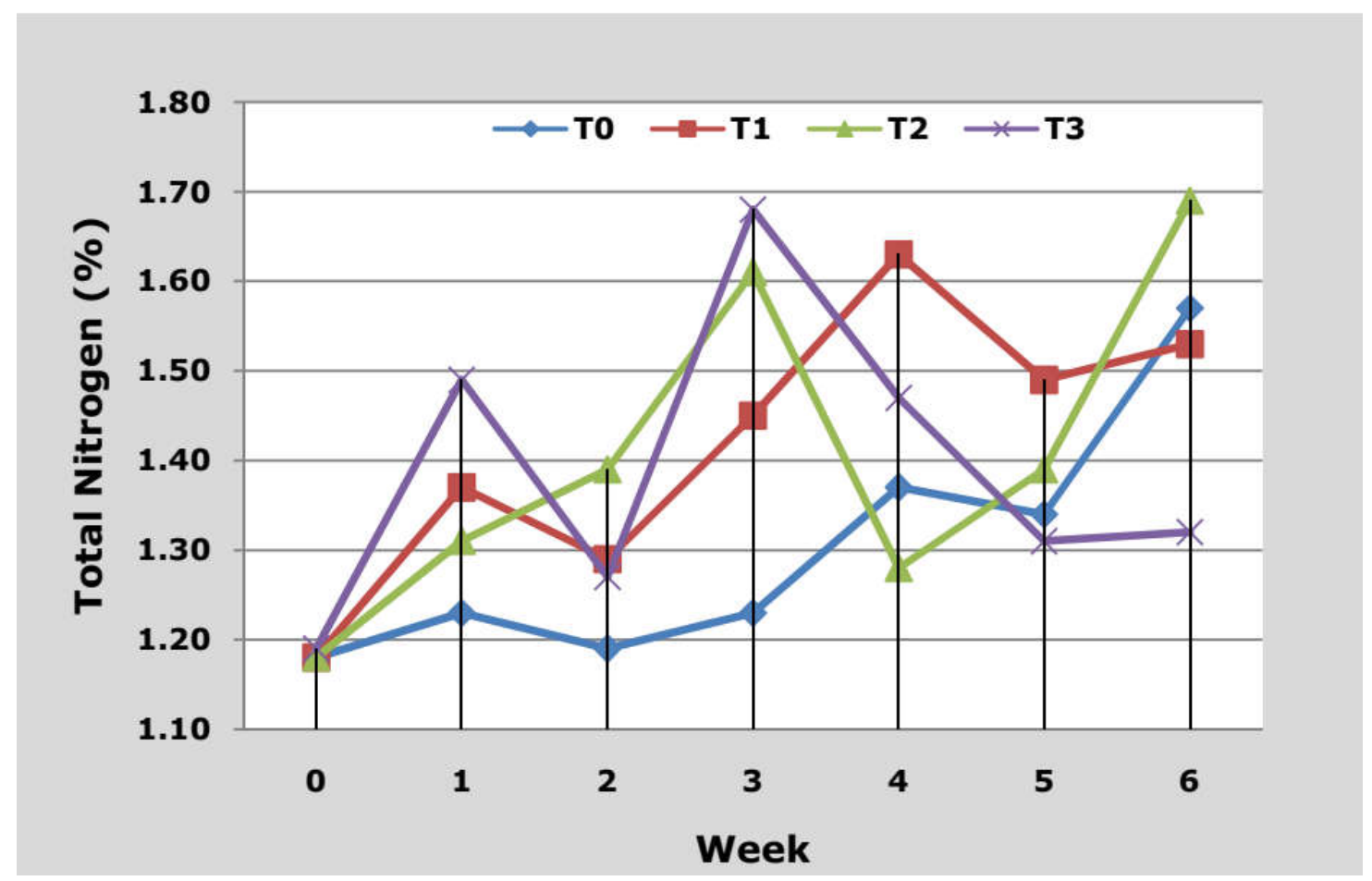

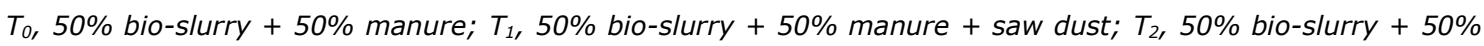
manure + rice straw; $T_{3}, 50 \%$ bio-slurry $+50 \%$ manure + tree leaves.

Figure 4: Changing pattern of total nitrogen (\%) during composting of bio-slurry

\section{Temperature}

Temperature as measured at the beginning of work was around $32{ }^{\circ} \mathrm{C}$ except $\mathrm{T}_{0}\left(29^{\circ} \mathrm{C}\right)$. At the end of 1 st week of after treatment with bulky materials, the temperature of the composting material decline to $29.67{ }^{\circ} \mathrm{C}$ in treated pits. At $4^{\text {th }}$ week the highest temperature was $34.03{ }^{\circ} \mathrm{C}$ $\left(T_{1}\right)$ among all treatments. After $4^{\text {th }}$ week the temperature in treatments ( $6^{\text {th }}$ week) it was stabilized to around $30{ }^{\circ} \mathrm{C}$. There was a very little fluctuation among the treatments during decomposition but all the treatments showed almost a similar flow of temperature over the period of time. After $6^{\text {th }}$ week the highest temperature was $31.76{ }^{\circ} \mathrm{C}$ for $\mathrm{T}_{1}$ and lowest temperature was $30.08{ }^{\circ} \mathrm{C}$ for $\mathrm{T}_{1}$ (Figure 3 ).

\section{Total Nitrogen}

Initial nitrogen content of Bio-slurry was around $1.18 \%$ which was not so bad. With the progress of composting, total nitrogen content slightly increased for all the treatments, though there were some fluctuations. Total nitrogen content at the end of $6^{\text {th }}$ week was highest $(1.69 \%)$ in the treatment where Bio-slurry treated with saw dust $\left(T_{1}\right)$ was used for decomposition. On the contrary, Bio-slurry treated with tree leaves showed lowest quantity of total nitrogen $(1.32 \%)$ at the end of 6th week (Figure 4$)$.

\section{$\mathrm{C} / \mathrm{N}$ ratio}

$\mathrm{C} / \mathrm{N}$ ratio of the manure sample was determined by dividing total organic carbon with total nitrogen. The $\mathrm{C} / \mathrm{N}$ ratio was not much high, around (18). After $1^{\text {st }}$ week $\mathrm{C} / \mathrm{N}$ ratio started to decline and varied from 14 to 17 . In T0, it was a bit lower (14) than other treatments. Without a little fluctuation, as the time advanced, $\mathrm{C} / \mathrm{N}$ ratio declined for all the treatments (Figure 5). At the end of the composting process highest $\mathrm{C} / \mathrm{N}$ ratio (15.81) was found in the treatment $\mathrm{T}_{1}$ (Bioslurry treated with saw dust) and lowest $\mathrm{C} / \mathrm{N}$ ratio was found in the treatment $\mathrm{T}_{2}$, (Bio-slurry treated with saw dust) (Figure 5). 
Al-Amin et al. (2020) Bang. J. Anim. Sci. 49 (2):142-150

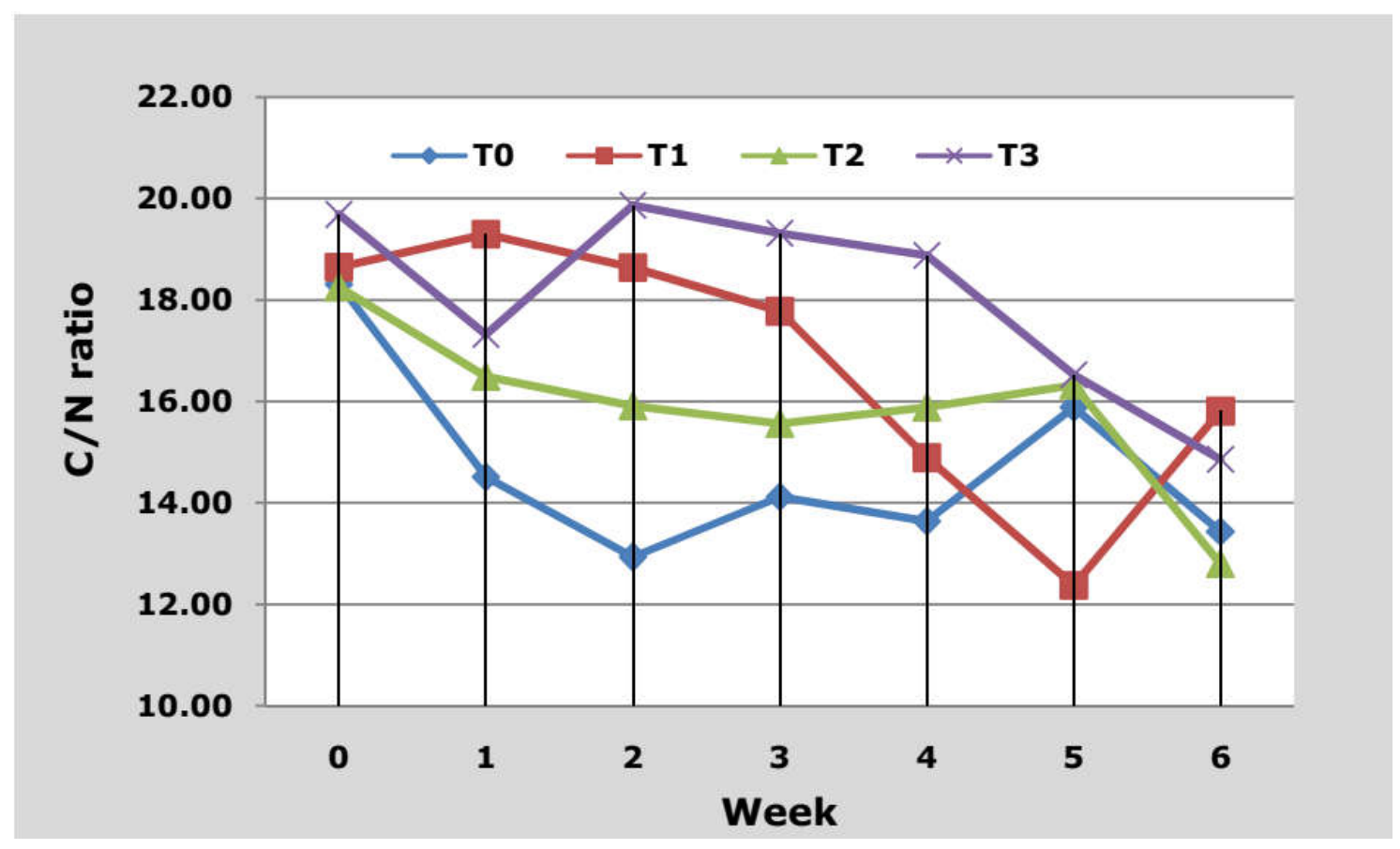

$T_{0}, 50 \%$ bio-slurry $+50 \%$ manure; $T_{1}, 50 \%$ bio-slurry $+50 \%$ manure + saw dust; $T_{2}, 50 \%$ bio-slurry $+50 \%$ manure + rice straw; $T_{3}, 50 \%$ bio-slurry $+50 \%$ manure + tree leaves.

Figure 5: Changing pattern of $\mathrm{C} / \mathrm{N}$ ratio during composting of bio-slurry

\section{Discussion}

\section{Changing pattern of different parameters during composting}

Bio-slurry composting leads to a volume reduction and to convert it in an organic-rich, soil-like product, through aerobic decomposition. Much of this reduction results from the loss of carbon dioxide, water and other minor gases to the atmosphere. Further reduction occurs as loose bulky materials are rendered into crumbly, fine-textured compost without any of the recognizable structure of the starting materials. During decomposition of Bio-slurry, disease causing organisms were also destroyed. The key factors affecting the biological decomposition process and/or the resulting compost quality are carbon nitrogen ratio, moisture content, oxygen supply, aeration, particle size, $\mathrm{pH}$, temperature, turning frequency, microorganisms, control of pathogens, degree of decomposition (Avnimelech et al., 2004).

\section{Changes of pH during composting of Bio- slurry by bulky materials}

The $\mathrm{pH}$ is an important factor that determines the quality of the compost (Bernal et al., 2009). The $\mathrm{pH}$ of compost material is dependent on the $\mathrm{pH}$ of the feed materials and the products of decomposition produced by microbial action. The change of $\mathrm{pH}$ was not so dramatic in the composting process of Bio-slurry.

The Figure 1 clearly indicated that $\mathrm{pH}$ of the composting sample at $1^{\text {St }}$ week was 8.40 to 8.77 . The $\mathrm{pH}$ of the composting materials at $1^{\text {st }}$ week was in alkaline range, which might have been due to the activation of composting process and at $2^{\text {nd }}$ week it was comparatively lower than $1^{\text {st }}$ week. The $\mathrm{pH}$ range as recorded in the composting pit was in line with the opinion of Cochran and Carney (2006) and Yang (2000) who said, "6.5-8.0 is the optimum range of $\mathrm{pH}$ in composting. Findings were stated by Epstein (1997) that increase in the $\mathrm{pH}$ level was due to the reduction of the volatile acids and its further 
combination with the ammonia gas released from the denaturing of protein.

Bio-slurry composting using tree leaves $\left(T_{3}\right)$ showed comparatively higher $\mathrm{pH}$ than the others which may be due to the higher rate of protein breakdown in this compost pit. At the end of composting process formation of $\mathrm{NH}_{3}$ was reduced as protein breakdown was almost finished. Moreover, protein, cellulose and hemicelluloses are easily degradable. Many of these compounds produce organic residues, referred to as humus matter.

\section{Changes of moisture content during composting of Bio-slurry by bulky materials}

Active microorganisms need a moist environment. Ideally, composting materials should be moist by 40 to $60 \%$ (Epstein, 1997). When conditions are too wet, water will fill the pore space needed for air movement, and anaerobic conditions can result. If conditions are too dry, the decomposition rate will slow down. Coarse material is especially helpful in this situation, as it increases the porosity allowing water to drain out and air to flow in. Moisture plays an essential role in the metabolism of microorganisms and indirectly in the supply of oxygen. Microorganisms can utilize only those organic molecules that are dissolved in water. A moisture content of 40 to 60 percent provides adequate moisture without limiting aeration. If moisture content falls below 40 percent, microbial activity will slow down, and will cease entirely below 15 percent. When the moisture content exceeds 60 percent, nutrients are leached, air volume is reduced, odours are produced (due to anaerobic conditions), and decomposition is slowed (Anonymous, 1996).

Figure 2 revealed that the moisture content of composting materials at $1^{\text {st }}$ week was $70-77 \%$ and mature compost had lowest moisture content $56 \%$ in $T_{1}$ treatment. The results showed that there was almost a gradual decline of moisture content for all the treatments including control treatment $\left(T_{0}\right)$. No sharp difference was observed in moisture loss among the treatments. Compound organic matter was broken down into carbon dioxide and water. This metabolic $\mathrm{H}_{2} \mathrm{O}$ was evaporated during composting process.

The moisture content of the composting materials as determined (56-68\%) was not in the ideal range. This finding has support of Sherman (2010) who demonstrated 40-65\% moisture is ideal in composting. However, the present finding differs with Yang (2000) who advocated a moisture content of $60-65 \%$ in composting.

\section{Temperature change during composting of Bio-slurry}

There is a direct relation between temperature and rate of oxygen consumption and consequently microbial activity. At high temperature, the oxygen uptake is greater; eventually the rate of decomposition is also faster. The temperature in the dumping site is increased, resulting from microbial activity and physiological process, may be noticeable within a few hours of waste disposal (Steger et al., 2007). During the decomposition of organic waste, they generate heat and the decomposition is most rapid when the temperature is between (32$60^{\circ} \mathrm{C}$ ). After an initial high temperature period of a few days to several weeks, compost pile temperatures will gradually drop (Epstein, 1997). To increase the rate of decomposition and reduce the composting time composting accelerator bulky materials was used for decomposition of Bio-slurry.

The obtained results explained that, Bio-slurry mixed with bulky materials pits which enhanced decomposition rate and formed $\mathrm{CO}_{2}$ and $\mathrm{H}_{2} \mathrm{O}$. This metabolic water evaporated into atmosphere using heat energy. Among the treatments $T_{1}$ showed the highest temperature over the composting period, which indicated maximum microbial population as well as maximum rate of decomposition and the lowest temperature was recorded for $T_{0}$ during the composting process.

\section{Effect of turning frequency on composting process}

Composting materials under decomposition with bulky materials were turned @ 7 day intervals. This was done because turning helped to proper aeration within the composting materials (Getahun et al., 2012). Bio-slurry composting is an aerobic process, which means it occurs in the presence of oxygen. During composting if the oxygen level falls in the large pores, parts of the compost pile can become anaerobic and producing methane gas. Oxygen is essential for microbial activities and for adequate decomposition to take place. With adequate aeration composting proceeds more rapidly, decomposition of plant materials can proceed. In the present study, a total of six turnings were 


\section{Bio-slurry compost adding with bulking materials}

made. This led to rapid decomposition resulting in quicker compost maturity.

\section{Total Nitrogen}

The results (Figure 5) showed that total Nitrogen content of the Bio-slurry compost was increased for treatments except $T_{0}$ and $T_{1}$. The changing pattern of $\mathrm{N}$ content in the composting material was fluctuated and all are not statistically significant. Zhao et al. (2013) showed the increased rate of nitrogen in bio-slurry composting. After 1st week of composting process, all the treatments showed an increased percentage of total nitrogen but the increase was lower in Bio-slurry pit without bulky materials as compared to others. At the end of the composting process, $\mathrm{N}$ content was still increased in case of To, $T_{1}$ and $T_{2}$, whereas other treatments contained less $\mathrm{N}$ than earlier.

\section{C/N Ratio}

$\mathrm{C} / \mathrm{N}$ ratio is one of the most important parameters that determine the extent of composting and degree of compost maturity. Irrespective of the materials used for composting, all the treatments attained drastic decrease of $\mathrm{C} / \mathrm{N}$ ratio in the final product compared to the initial raw materials. $\mathrm{C} / \mathrm{N}$ ratio of the composted materials narrowed down with the advancement of the period of decomposition. It was reported that the $\mathrm{C} / \mathrm{N}$ ratio narrowed down as nitrogen remain in the system, while some of the $\mathrm{C}$ is released as $\mathrm{CO}_{2}$ (Sadasivam and Manickam, 1992). During bio-conservation of the materials, concentration of carbon was reduced while that of nitrogen was slightly increased, resulting in the reduction of $\mathrm{C} / \mathrm{N}$ ratio at the end of the composting process (Figure 5). The reduction can be attributed to the loss in total dry mass due to losses of $\mathrm{C}$ as $\mathrm{CO}_{2}$ (Hamoda et al., 1998). Ammonium-N $\left(\mathrm{NH}_{4}-\mathrm{N}\right)$ and nitrate- $\mathrm{N}\left(\mathrm{NO}_{3}-\mathrm{N}\right)$ will also undergo some changes. $\mathrm{NH}_{3}$ levels were in increase in the initial stages but declining towards the end (Liao et al., 1995). In several instances, $\mathrm{NO}_{3}$ concentration were less during the initial phases but gradually increased towards the end (Pereira Neto and Stentiford, 1992). The consumption of nitrogen and carbon by the composting microbes is not same. They need more carbon as to nitrogen, which might be the reason behind the increase in the nitrogen percentage with respect to the remaining biomass. During the microbial growth, approximately 25 to 30 parts of carbon are needed for every unit of nitrogen (Epstein,
1997). This clearly explains the variation in the amount of $\mathrm{C}$ and $\mathrm{N}$ in the composting pit as observed in the present study. The highest $\mathrm{C} / \mathrm{N}$ ratio (20.78) as recorded in the final product of the present experiment is an ideal one as supported by the findings of Sherman (2010) who claimed a $\mathrm{C} / \mathrm{N}$ ratio of 25 to 30 is preferred.

\section{Conclusion}

Bio-slurry using bulky materials as an accelerant leads to rapid decomposition and attaining stability of compost. During the composting process, bulky materials decomposed organic compounds, which consist of carbohydrates, sugar, proteins, fats, cellulose and lignin. Several physical and chemical changes occurred during the process of decomposition. As the composting proceeded, moisture content was gradually decreased. The results revealed that, there was a sharp change $\mathrm{C} / \mathrm{N}$ ratio fall down. $\mathrm{C} / \mathrm{N}$ ratio is one of the most important parameters used for determining compost maturity. Bio-slurry composting by using tree leaves as a composting accelerator had the highest $\mathrm{C} / \mathrm{N}$ ratio (19.87) which is not acceptable for safe use in crop production. The lowest moisture observed in $\mathrm{T}_{1}(56.34 \%)$. From the result, it may be concluded that bulky materials treated compost is more effective compared to only Bio-slurry compost.

\section{References}

Alam S (2006). Production of organic manure in Bangladesh. A report from Bangladesh Livestock Research Institute. Savar, Dhaka, Bangladesh.

Anonymous (1996). Composting fact sheets. Ministry of Agriculture and Food, British Columbia. USA.

Avnimelech $\mathrm{Y}, \mathrm{R}$ Eilat, $\mathrm{Y}$ Porat and PA Kottas (2004). Factors affecting the rate of windrow composting in field studies. Compost Science and Utilization 12(2):114-118.

Bernal MP, JA Alburquerque and R Moral (2009). Composting of animal manures and chemical criteria for compost maturity assessment. A review. Bio-resource Technology 100(22): 5444-5453.

Cochran BJ and WA Carney (2006). Basic Principle of Composting: What is Composting? LSU Agriculture Center, Research and Extension 2602: 1-12.

Dhobighat C and T Painyapani (2006). Physicochemical Analysis of bio-slurry and farm yard manure for comparison of nutrient contents and other benefits so as to better promote 
Al-Amin et al. (2020) Bang. J. Anim. Sci. 49 (2):142-150

bio-slurry, Yashoda Sustainable Development (P) Ltd, Final Report, Nepal pp. $30-31$.

Epstein E (1997). The science of composting. Technomic Publishing Company, Lancaster, Pennsylvania, USA. ISBN No. 1-56676-478-5.

Fentaw E (2010). Bio-slurry in Ethiopia: what is it and how to use it?. Institute for Sustainable Development (ISD) and National Biogas Program Ethiopia Coordination Office, Addis Ababa.23 pp.

Garg RN, H Pathak, DK Das and RK Tomar (2005). Use of fly ash and biogas slurry for improving wheat yield and physical properties of soil. Environmental Monitoring and Assessment 107(1-3): 1-9.

Getahun T, A Nigusie, T Entele, TV Gerven and BV der Bruggen (2012). Effect of turning frequencies on composting biodegradable municipal solid waste quality. Resources, Conservation and Recycling 65:79-84.

Hamoda MF, HA Abu Qdais and J Newham (1998). Evaluation of municipal solid waste composting kinetics. Resources, Conservation and Recycling 23: 209-393.

Islam AABM (2013). Bioslurry ultimate choice of bio-fertilizer. Open Access Scientific Reports 2(4): 123-127.

Islam MS (2006). Use of bio-slurry as organic fertilizer in Bangladesh Agriculture. International Workshop on the Use of Bioslurry Domestic Biogas Programs 27-28 September 2006. Bangkok, Thailand. pp. 2728.

Jackson ML (1962). Soil chemical analysis. Constable and Co. Ltd. London.

Liao PH, AC May and ST Chieng (1995). Monitoring process efficiency of a full-scale in-vessel system for composting fisheries wastes. Bioresource Technology 54: 159-163.

Mohabbat U, SKH Ranjit, $M$ BadirulIsalm and $\mathrm{K}$ Shahabuddin (2008). Bio- slurry management and its effect on soil fertility and crop production in Bangladesh, Bangladesh Agricultural Research Institute. Soil Science Division and On-Farm Research Division Gazipur 1701:8-22.

Pereira Neto JT and EI Stentiford (1992). A low cost controlled windrow system. Acta Horticulture 302: 141-152

Sadasivam S and A Manickam (1992). Biochemical methods for agricultural sciences. Wiley Eastern Ltd. and Tamil Nadu Agricultural University, Coimbatore.

Satyanarayana V, PV Prasad, VRK Murthy and KJ Boote (2002). Influence of integrated use of farmyard manure and inorganic fertilizers on yield and yield components of irrigated lowland rice. Journal of Plant Nutrition 25(10): 2081-2090.

Sherman R (2010). Large-scale organic materials composting. North Carolina Cooperative Extension Service. pp. 1-15.

South Netherlands Volunteers (2012). Integrated use of bio-slurry and chemical fertilizer for vegetable production. Royal Society for Protection of Nature 2012:8.

Steger K, A Jarvis, T Vasara, M Romantschuk and I Sundh (2007). Effects of different temperature management on development of Actinobacteria populations during composting. Research in Microbiology 158(7):617-24.

Warnars L and H Oppenoorth (2014). A study on bioslurry results and uses. BukuPaket. TerbitMaret: p 52.

Yang SS (2000). Recent advances in composting. Issues in the Management of Agricultural Resources. Food and Fertilizer Technology Center \& National Taiwan University, Taipei, Taiwan ROC, pp.195-216.

Zhao HY, LI Jie, JJ Liu, YC Lü, XF Wang and ZJ Cui (2013). Microbial community dynamics during biogas slurry and cow manure compost. Journal of Integrative Agriculture 12(6):10871097. 